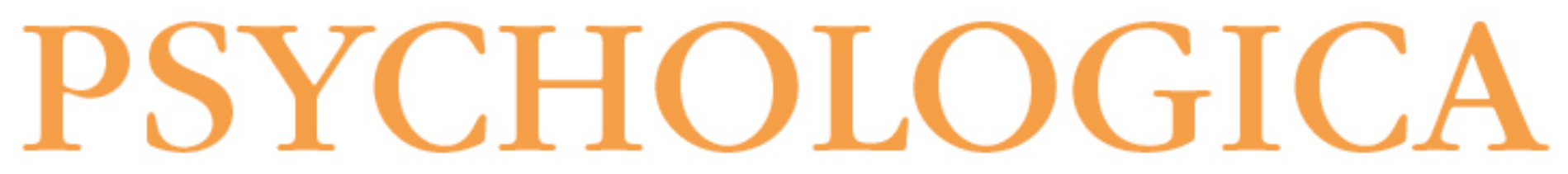

\title{
Sherif's theoretical concepts and intergroup relations studies: notes for a positive interdependence
}

\author{
Autor(es): $\quad$ Valentim, Joaquim Pires \\ Publicado por: Imprensa da Universidade de Coimbra \\ URL \\ persistente: URI:http://hdl.handle.net/10316.2/3486 \\ DOI: $\quad$ DOI:http://dx.doi.org/10.14195/1647-8606_52-2_25 \\ Accessed : $\quad$ 26-Apr-2023 16:31:37
}

A navegação consulta e descarregamento dos títulos inseridos nas Bibliotecas Digitais UC Digitalis, UC Pombalina e UC Impactum, pressupõem a aceitação plena e sem reservas dos Termos e Condições de Uso destas Bibliotecas Digitais, disponíveis em https://digitalis.uc.pt/pt-pt/termos.

Conforme exposto nos referidos Termos e Condições de Uso, o descarregamento de títulos de acesso restrito requer uma licença válida de autorização devendo o utilizador aceder ao(s) documento(s) a partir de um endereço de IP da instituição detentora da supramencionada licença.

Ao utilizador é apenas permitido o descarregamento para uso pessoal, pelo que o emprego do(s) título(s) descarregado(s) para outro fim, designadamente comercial, carece de autorização do respetivo autor ou editor da obra.

Na medida em que todas as obras da UC Digitalis se encontram protegidas pelo Código do Direito de Autor e Direitos Conexos e demais legislação aplicável, toda a cópia, parcial ou total, deste documento, nos casos em que é legalmente admitida, deverá conter ou fazer-se acompanhar por este aviso.

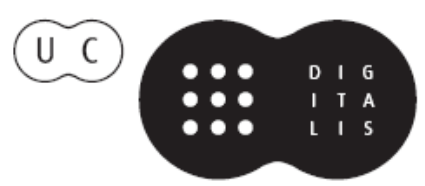




\section{NÚMERO 52}

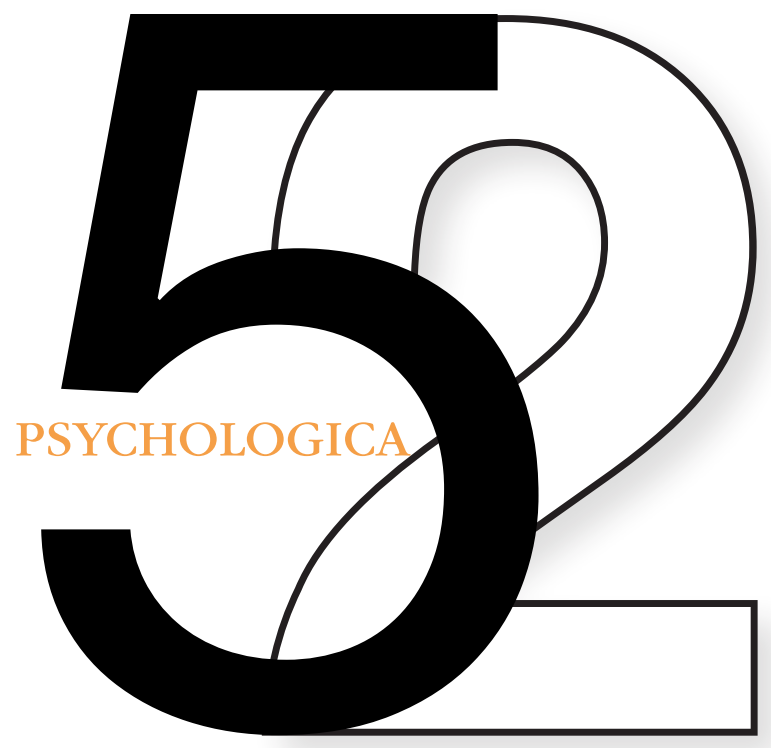

VOLUME II

IMPRENSA DA UNIVERSIDADE DE COIMBRA

FACULDADE DE PSICOLOGIA E DE CIÊNCIAS DA EDUCAÇÃo DA UNIVERSIDADE DE COIMBRA 


\title{
Sherif's theoretical concepts and intergroup relations studies: notes for a positive interdependence'
}

\author{
Joaquim Pires Valentim²
}

Sherif's theoretical concepts on intergroup relations are not merely a historical landmark for surpassing individualistic perspectives on that domain. They could also be, nowadays, useful theoretical tools for those who are interested in studying societal functioning. The main point of this article is to argue that social psychology can benefit from the discussion and use of Sherif's concepts, in order to provide a more comprehensive analysis for the study of intergroup relations than those deriving from a strict use of the categorization model. This is illustrated here with two examples of supra-national identities (European identity and the lusophone community) studies which could benefit from the use of Sherif's ideas, especially the notion of superordinate goals. However, despite the pertinence and utility of Sherif's concepts, several weaknesses of realistic conflict theory of intergroup behaviour should also be noted, namely, the tendency to assume that conflict is always negative. This undermining idea is discussed here based not only on the perspective of disadvantaged groups but also on positive evidence from the benefits of socio-cognitive conflict provided by two fields of European social psychological studies: social developmental psychology and research on minority influence.

KEY-WORDS: realistic conflict theory; intergroup relations; social identity; national identity

\section{Before M. Sherif}

Several theoretical concepts started developing in social psychology a few years before the 2nd. World War, aiming to understand complex social phenomena related to intergroup relations, stereotypes, prejudice and discrimination. This immense domain has attracted several researchers, whose work, since those days, has marked the history of social psychology. The fact that racism and the

\footnotetext{
1 This article is a revised and shorter version of the Turkish chapter published in the book edited by Sertan Batur and Ersin Aslitürk in hommage to M. Sherif: Batur, S. \& Aslitürk, E. (Eds.) (2007). Muzaffer Serif'e Armagan. Muzaffer Serif'ten Muzafer Sherif'e [From Muzzafer Serif to Muzafer Sherif: Essays in honor of Muzafer Sheriff. Istambul: Iletisim.
}

2 Faculdade de Psicologia e de Ciências da Educação da Universidade de Coimbra (jpvalentim@fpce.uc.pt). 
defence of eugenics policies were, at that time, developing in Europe, along with the establishment of dictatorial regimes, and, mostly, with the rise of the Nazi barbarity that directly hit some of those Europeans researchers, is, of course, a main factor for these theoretical concerns. No wonder that, in such a tragic context, social psychologists tried to find scientific explanations for what they were witness to, which marked their century, if not the history of humanity.

It was also in this socio-historical context that the theory of frustration - aggression (Dollard, Doob, Miller, Mowrer \& Sears, 1939) and especially the theory of authoritarian personality (Adorno, Frenkel-Brunswik, Levinson \& Sanford, 1950) developed. These two theories have marked the scientific field as well as common sense until the present day. The first one is a psychoanalytic approach which still inspires common sense and social analysis as far as, for instance, racism and terrorism are concerned, through the conception that frustration inevitably leads to aggression and through the application of the idea of a "scapegoat" in the analysis of numberless social situations. In his turn, Adorno's conception of authoritarian personality, which started with Marxist analysis and later adopted psychoanalysis perspectives, constitutes a remarkable theoretical effort to build a psychology of fascism, prejudice and discrimination with important consequences, both for psychological theory and for political action (cf. Billig, 1984; Brown, 1965).

However, besides the possible relevancy they can assume in certain situations, these concepts present several insufficiencies, deriving mostly from the individualistic approach they adopt in social phenomena analysis. We are dealing with conceptions which, in F. Allport's (1924) vein'3, are based on explanatory mechanisms placed somewhere in the psychology of the members of the groups at stake, even when analysing the relations between groups in complex social, political and historical situations.

\section{Some new challenging ideas and notions}

So, the fact that social psychology courses and handbooks usually keep M. Sherif's intergroup studies as a landmark in surpassing those individualistic perspectives should not be a surprise. Triandis (1979, p. 321) considers him "the most important social psychologist in the history of the field".

One of the basic premises of Sherif's work $(1962$, p. 8) in this area is that "we cannot extrapolate from the properties of individuals to the characteristics of

3 According to F. Allport (1924, p. 4), "there is no psychology of groups which is not essentially and entirely a psychology of individuals". 
group situations". In this perspective, Sherif and his associates carried out, in the USA, a number of researches in holiday camps for boys (see, especially, Sherif, 1966; cf. also Monteiro, 2002), namely, the famous “Robber's Cave" study, so called for having been developed in a field near a hideaway said to have been used by Jesse James. These studies were developed in "natural scenarios", during different periods of the life of real groups and the relations between them. Over a few weeks researchers tried to recreate these periods (groups formation, establishment of intergroup conflict and hostility between them and, finally, the reduction of conflict and the reestablishment of harmony between groups) and used different methods of data collection.

Sherif's explanation for the observed phenomena is based on functional relations between groups. When two groups are in a negative interdependence situation, i.e., when only one can reach a goal which is important for both of them, when there is a real conflict of interests, relations between groups are marked by a strong antagonism or hostility and by favouritism of the ingroup, along with an increase of solidarity inside each group. When groups need each other to accomplish a common project or to reach superordinate goals, hostility reduces, representations of the other group become more favourable and relations between groups tend towards harmony. Theoretically, this explanation surpasses the individualistic paradigms and, simultaneously, raises innumerable issues and challenges concerning possible applications and social interventions. The more so as, according with the proposed conceptual frame, the incompatibility of goals applies both to a struggle for material or physical goods (for ex., natural resources and territory) and to a struggle for symbolic resources (for ex., power, prestige and authority). In fact, this conceptual frame has been used in the resolution of conflicts between groups in different contexts and domains, namely, in industry, schools and international relations.

Without being exhaustive, let us analyse, briefly, three specific aspects regarding which Sherif's works can be particularly valid for social psychologists: in terms of some of the measures frequently preconized to reduce conflicts between groups; in terms of the connection between the study of the intergroup relations and intragroup processes and, finally, in methodological terms.

As for the several measures which have traditionally been - and still are - proposed to reduce conflicts between groups, Sherif's theory reconceptualizes their role considering whether they are inserted (or not) in common projects or in a situation of positive interdependence between groups. It remains especially clear that contact or the opening of communication channels between groups, aiming to reduce conflict, are not enough per se because "if contact between hostile groups takes place without superordinate goals, the communication channels serve as 
media for further accusations and recriminations" (Sherif, 1958/2001, p. 70). And the same principle can be applied to other measures, like information diffusion, which characterizes a certain rationalist illusion of the intervention where, for instance, racist prejudice and discrimination are concerned: "favourable information about a disliked out-group tends to be ignored, rejected, or reinterpreted to fit prevailing stereotypes" (Sherif, 1958/2001, p. 70). According to Sherif, generally, different strategies to reduce tensions and conflicts between groups "acquire new significance and effectiveness when they become part and parcel of interaction processes between groups oriented toward superordinate goals which have real and compelling value for all groups concerned" (Sherif, 1958/2001, p. 70).

The issue of the connection between intergroup and intragroup processes has a particular theoretical pertinence since a certain separation has characterized the study of the intergroup and the intragroup. Actually, Sherif's works can constitute a starting point to bridge this separation, by showing that, in the study of relations between groups it is possible, and probably advantageous, not to neglect what happens inside the groups. By studying, simultaneously, the intragroup and the intergroup, Sherif's experiments show that the explicitness of the ingroups' hierarchical structures could be enhanced by competition between groups. That is to say: a differentiation inside the groups can occur simultaneously with a differentiation between groups, which contradicts one of the main presumptions of the categorization model (cf. Doise \& Lorenzi-Cioldi, 1989; Valentim, 2008).

To finish this issue, a very brief reference to the place methodology holds in scientific research. In respect to this, Sherif's works - namely the Robber's Cave study (Sherif, Harvey, White, Hood, \& Sherif, 1961)4- can be particularly didactic concerning the good use of the immense arsenal of methodological and statistical techniques from which researchers can benefit nowadays. Sherif's use of different methodologies (observational methods, sociometric technique, stereotype ratings, and techniques adapted from the laboratory) clearly shows how, methods - in the plural -, in scientific research, must be used as tools in the service of the resolution of theoretical and social problems.

However, in spite the richness, virtualities and potentialities of the realistic conflict theory, it is important to notice that subsequent research would question this explanation and lead psychosocial studies on intergroup relations in a different direction.

4 Also available on internet on Classics in the History of Psychology page: http://psychclassics.yorku.ca/Sherif/ 


\section{Sherif's notions: a tool to go beyond "an over-extension of social identity theory"?}

Researches carried out with the minimal group paradigm show that, unlike Sherif's theoretical concepts, a conflict of interests between groups isn't necessary to promote discrimination behaviours between groups. Social categorization in terms of an ingroup and of an outgroup is enough to reveal discrimination in favour of the group to which the individual belongs (Tajfel, Flament, Billig \& Bundy, 1971). According to the proposed explanation (Tajfel, 1972b), individuals acquire a social identity by belonging to different groups, and the need for a positive evaluation of themselves requires them to establish comparisons between groups favourable to their own.

By placing identity in the centre of intergroup relations analysis, social identity theory differed from other contemporaneous theories which aimed to articulate psychological and sociological perspectives in the study of intergroup processes. The notion of "common fate" (Lewin, 1948; Rabbie \& Horwitz, 1969), the importance of group projects and their interdependence emphasized by Sherif are not considered in the conceptions of the "Bristol School" researchers. These conceptions are based on the link between social comparison and social identity. However, it is not difficult to arge that the explanation model proposed by social identity theory is placed at the individual level (cf. Amâncio, 2002; Billig, 1996; Deschamps \& Devos, 1998). Actually its conceptions are based, exclusively, on two basic psychological processes: a cognitive mechanism (categorization, through which the individual overestimates intergroup differences and intragroup similarities) and a motivational mechanism (the need for a positive evaluation of oneself which leads to discrimination). What really matters is the individual need for a positive evaluation of oneself.

And, later on, this model's cognitivism was emphasized by the developments in self-categorization theory (Turner, Hogg, Oakes, Reicher \& Wetherell, 1987; cf., also, Turner \& Oakes, 1986) which introduce the self-categorization postulate with three inclusive hierarchic categorization levels: as an individual, as a group member and as a human being. According to this theory "there is (...) a functional antagonism between the salience of one level of self-categorization and other levels" (Turner et al., 1987, p. 49).

We here stand before a fundamentally cognitive model which, in a certain way, expresses, also, the supremacy usually assumed by intra-individual explanations in social psychology, like those that precede Sherif's works, as mentioned at the beginning of this article.

On the other hand, there is not, here, a theorization leading to an articulation and an integration of the intra-individual processes with social variables. These 
two characteristics - centering on intra-individual mechanisms and the absence of theoretical articulation with social, political and cultural-historical processes - characterize, to a large extent, the development of the many works which, since the 70's, have been elucidating us about cognitive processes involved in relations between groups. Lately, some social psychologists have analysed the insufficiencies and the virtues of these conceptions in terms of the contribution to the understanding of the social phenomena at stake (cf., especially, Billig, 2002; Sanchez-Mazas \& Licata, 2005). I would like to emphasize here, that a criticism of this path can already be found in texts written by the founder of social identity theory himself. Let us notice that $\mathrm{H}$. Tajfel pronounced against a social psychology based on "experiments in a vacuum" (Tajfel, 1972a); in a subsequent text, he also explicitly criticizes some of the negative consequences deriving from "an over-extension of what has come to be known as the 'social identity' theory" (Talfel, 1984, p. 699).

To avoid an accumulation and a juxtaposition of studies in a social vacuum, when they approach complex social phenomena, such as those which characterize the study of relations between groups in a larger social context, social psychologists could benefit from the use of other theoretical tools besides those deriving from the strict categorization model, especially some of Sherif's notions.

Let us briefly analyse two examples dealing with intergroup relations and supranational identities: one from the area of studies in Europe and the other from the area of the luso-tropicalism role in Portuguese and African intergroup attitudes in contemporary Portuguese society.

\section{Two examples}

The model proposed by social identity and self-categorization theories is supposed to fit particularly well in the European identity case. The principle of an antagonism between different levels of categorization (regional, national, supra-national) and a class inclusion logic, especially, should be easily applied to the study of the connection between European identity and other less inclusive identities.

And, in fact, in a revision of social psychology literature on European identity studies, Doise \& Devos (1999, p. 11) come to the conclusion that "much research in this area is based on Tajfel's and Turner's theory about social categorization and identity". However, in this revision, some insufficiencies of this model arise to account for the "plurality of patterns of relationships between such identities" ( $p$. 11). These are not confined to an antagonism, which would be expected, according to this model, between regional identity, national identity and European identity. 
Instead of being necessarily exclusive, these identities can express themselves simultaneously, in a concomitant way. Doise \& Devos (1999, p. 21) underline the importance of a social psychology that analyses the European case more in terms of interdependence bonds - which link (or can link) the Europeans among themselves -, than in terms of identity. "A Europe to do what together?" (p. 21). They stand up for the idea that, in this perspective, the study of human rights, as normative social representations, should assume a privileged role. Given such a notion, it is not difficult to understand the reason why these authors propose an approach in which "an important role should be given to classical theories in social psychology such as those of Sherif on superordinate goals and of Rabbie on common fate" (p. 11), as well as Rabbie's more recent works on a behavioural interaction model (Rabbie, Schot \& Visser, 1989).

The second brief example proceeds from the study of the role of luso-tropicalism and lusophone community 5 in Portuguese contemporary society. Luso-tropicalist theory has been brought forward since the thirties by the Brazilian sociologist G. Freyre (see, especially, 1933/n.d.) attributing a special skill to Portuguese people for peaceful and benevolent relations with tropical people and the absence of prejudice among the Portuguese. Linked with colonial ideologies, between the 50's and the 70's, these ideas were broadly disseminated in Portuguese society in which, nowadays, they still shape social knowledges and practices, namely in the domains of national identity, prejudice, racism and perception of social conflicts.

In the last few years a series of psychosocial researches have been carried out in Portugal with university students (Portuguese and African students who live in Portugal) about social representations of luso-tropicalism and lusophone community (Valentim, 2003, 2005a, 2005b). The results obtained show that, in general, there is an opposition between the Portuguese and Africans in what concerns luso-tropicalism and lusophony: the Portuguese adhere to these ideas and Africans refuse them. However, there are several modulations characterizing the positions of the Portuguese individuals, and one should notice that the valorization of the lusophone principle by the Portuguese participants is not reducible to a surplus value in terms of positive social identity.

On the level of attitudes between groups, no evidence is found of the "Portuguese specificity" expressed in luso-tropicalist beliefs. In fact, there is evidence of a reciprocal prejudice between Portuguese and African people as well as the fact that Africans express less prejudice towards Europeans, in general, than towards the Portuguese, specifically. On the other hand, the data on prejudice between

5 The word luso means Portuguese and is related with Lusitania, the name of the ancient Roman province, which occupied a part of the present Portuguese territory. 
the Portuguese and Africans are difficult to interpret in the context of the strict frame of social identity theory. Africans express a greater prejudice towards the Portuguese than the Portuguese towards Africans. This seems to be compatible with realistic conflict theory, according to which a low-status should intensify the antagonism towards the high-status group. Finally, it must be referred that the Africans reveal, also, a greater inner solidarity and homogenization of the ingroup, which can lead us to the hypotheses that this group's members, eventually, "close ranks" because of the perception of a negative interdependence or incompatibility between both (Portuguese and Africans), which could be emphasized by an ethnicization of social relations.

To synthesize, more than the simple effects of a presumed Portuguese exceptionality at the service of a positive national identity, which can be at stake, here, is the unsuitableness between these identitarian myths and the absence of real conditions for the creation of social links of interdependence between different peoples united by a history and by a common language: i.e., it might be necessary to recognize that, perhaps the real absent factor is the lack of capacity, in postcolonial societies, of making a common project, able to mobilize these groups towards "superordinate goals".

\section{Is conflict always bad and must it be always avoided?}

I am not trying to hide the existence of weaknesses in the realistic conflict theory (regarding this issue, cf. the excellent analysis of Taylor \& Moghaddam, 1994). One the critiques advanced of Sherif's conceptions regards the tendency to assume that conflict is always negative. The value of this idea, which undermines the whole realistic conflict theory, is doubtful, namely, in terms of relations between groups in a large social context. It's obvious that groups with conflicts and strong divergences hardly constitute good contexts for human development. However, there are situations in which conflict may not necessarily be negative. Especially when we consider disfavoured groups in situations of inequality, injustice or even exploitation, the fact of facing conflict and struggling, can give impulse to decisive social changes - as History has taught us so many times. Curiously, Tajfel's theoretical propositions can help to explore this idea. Actually, the analysis of possible strategies that can be adopted to change a situation of disadvantage or inferiority is conceptualized by Tajfel (cf., for instance, Tajfel, 1978/1983; Tajfel \& Turner, 1979/2001) in terms of an opposition between belief systems based on social mobility (associated to individual strategies) and on social change (associated to collective strategies). Collective strategies are accomplished, among others, namely through social competition, expressed by a direct confrontation with the 
outgroup, clearly involving conflict situations and antagonism in the sense of the realistic conflict theory. However, as Taylor \& Moghadam (1994, p. 85) point out, each form of "social change necessarily involves intergroup confrontation, since one group's efforts to improve its position vis-à-vis the dominant group will be met by a reaction from those attempting to maintain or improve their own relatively favorable position".

But this is not the only perspective which underlines the structuring role that conflict can have. One of the areas where this role can be especially in evidence is social psychology of development, within which several researches have demonstrated the favourable effects of socio-cognitive conflict under certain conditions. According to the explanation proposed by the Geneva authors (cf., especially, Doise \& Mugny, 1984; Mugny, 1985), it is the attempt to overcome a conflict, that is at once cognitive (between answers) and social (between partners, i.e. inserted in relationships between individuals to whom it causes a social problem) that leads to new cognitive elaborations. However, not all interactions between individuals with different solutions for the same problem lead to cognitive progresses. To a large extent, these depend on conflict resolution procedures which can be relational or socio-cognitive. Relational regulations aim, mostly, to maintain or establish social relations, avoiding conflict or divergence (for instance, through acquiescence or conformity). On the other hand, socio-cognitive regulations, in a certain sense dissociated from relational ones, by assuming divergence focus on the contents, on the task, imply the comparison and an integration of different answers or contradictory solutions for a same problem. Only socio-cognitive resolutions allow restructurings which can originate cognitive progresses, because they focus on the confrontation of different points of view. That is to say, in order for these favourable effects to exist, confrontation must be rational, assume a conflict of ideas or arguments, and be immune to relational aspects (those of personal, power, prestige or authority) at stake, in the situation.

These ideas do not apply only to the specific domain of cognitive development, since the opposition between "more social type regulations (based on imitation) and more cognitive type regulations (based on conflict)" (Doise, 1987, p. 242) constitutes a main theme in social sciences. An opposition particularly well defined in Bales' (1950) distinction between socio-emotional behaviour and task-related behaviour. This scheme can even constitute a reading grid for several research currents in social psychology (Doise, 1987). Focusing, mainly, on the issue of social reproduction, social psychology has privileged the study of submission and compliance processes (i.e., regulations of "relational" type) putting aside the study of innovation and expression of divergences (i.e., regulations of a "sociocognitive" type). 
In respect of this issue, one of the best examples comes from studies on influence of minorities (Mugny, 1982). In a very schematic way, regulations of a relational type would be predominant in majority influence forms and regulations of socio-cognitive type would be predominant in minority influence. As far as the former are concerned, influence could exert itself mostly at the public level, as the adoption of new answers can mostly express compliance phenomena. Minority influence can be more effective at the private level, leading to an internal process of comparing the answers, to a reorganization of the terms in which the issue is considered and, under certain conditions, to an influence delayed in time. That is to say, one would appeal to the reduction of divergences, to "relational regulations", and the other one to conflict, to "socio-cognitive regulations". And as well as influencing forms associated with majorities and compliance may imply, only, a immediate and superficial public acceptance, conflict relational regulations can also lead only to acquiescence and to a superficial answer without a cognitive restructuring that might lead to new individual cognitive elaborations.

Synthetically, conflict - the expression of divergences and open confrontation between positions - can be fundamental to rendering possible processes of social change and innovation, as well as new cognitive elaborations and, at the group level, might also be able to stop forms of impoverished collective decisions or "groupthink".

The point, here, is not the defence of conflictuality, since, there are, obviously, innumerable deleterious forms of conflict. The point, here, is to underline that, under certain social conditions, at several levels - in terms of individual, interindividual, group and in intergroup relations processes - conflict can have a positive role, and the idea of opposition between two ways of solving conflict can be an important theoretical tool. Besides the historical analysis grid which expresses a traditional tension in social psychology between a relational pole and a conflictual one, there is here an echo of ideas in favour of a space of argumentative debate à la Habermas (1984) or of a democratic political organization based on active citizenship (see also, Judt, 2010, chap. 5). That is to say, based on an open, plural and conflictual expression of divergences between social actors.

\section{Conclusion}

A certain "social vacuum" characterizes some of the contemporary dominant models in intergroup relations research, which are mostly focused on intra-individual mechanisms. For social psychologists interested in studying societal functioning, Sherif's predecessor concepts are useful theoretical tools in order to provide a more integrated and comprehensive analysis of intergroup relations phenomena 
in complex social, historical and political situations. However, if, on the one hand, Sherif's theoretical notions can be important for the study of objective conditions of intergroup relations in a larger social context, on the other hand, it is also true that other psychosocial theories can help to overcome some of the weaknesses of realistic conflict theory, namely, concerning the role of conflict.

In other words, if description, comprehension, explanation and eventually also intervention in intergroup relations phenomena in large social contexts were a superordinate goal for social psychologists with different approaches, it might be useful to establish a positive interdependence situation between realistic conflict theory and other theoretical models of social psychology, a situation able to congregate efforts towards this "common project".

\section{References}

Adorno, T., Frenkel-Brunswick, E., Levinson, D., \& Sanford, R. (1950). The authoritarian personality. New York: Harper and Row.

Allport, F. H. (1924). Social psychology. Boston: Houghton Mifflin.

Amâncio, L. (2002). Identidade social e relações intergrupais. In J. Vala \& M. B. Monteiro (Eds.), Psicologia Social (5 ${ }^{\text {th }}$ ed., pp. 387-409). Lisboa: Fundação Calouste Gulbenkian.

Bales, R. F. (1950). Interaction process analysis. A method for the study of small groups. Chicago: University of Chicago Press.

Billig, M. (1984). Racisme, préjugés et discrimination. In S. Moscovici (Ed.), Psychologie sociale (pp. 449-472). Paris: PUF.

Billig, M. (1996). Remembering the particular background of social identity theory. In W.

P. Robinson (Ed.), Social groups and identities. Developing the legacy of Henri Tajfel (pp. 337-357). Oxford: Butterworth-Heinemann.

Billig, M. (2002). Henri Tajfel's 'Cognitive aspects of prejudice' and the psychology of bigotry. British Journal of Social Psychology, 41(2), 171-188.

Brown, R. (1965). Social psychology. New York: The Free Press.

Deschamps, J. C., \& Devos, T. (1998). Regarding the relationships between social identity and personal identity. In S. Worchel, J. F. Morales, D. Páez, \& J.-C. Deschamps (Eds.), Social identity. International perspectives (pp. 1-12). London: Sage.

Doise, W. (1987). Idées nouvelles et notions anciennes. In J.-L. Beauvois, R.-V. Joule, \& J.-M. Monteil (Eds.), Perspectives cognitives et conduites sociales: Vol 1. Théories implicites et conflits cognitifs (pp. 229-244). Cousset: DelVal.

Doise, W., \& Devos, T. (1999). Identité et interdépendance: pour une psychologie sociale de I'Union Européenne. Psychologie et Société, 1, 11-27.

Doise, W., \& Lorenzi-Cioldi, F. (1989). Patterns of differentiation within and between groups In J. P. Oudenhoven \& T. M. Willemsen (Eds.), Ethnic minorities. Social psychological perspectives (pp. 43-58). Amsterdam: Swets \& Zeitlinger.

Doise, W., \& Mugny (1984). The social development of the intellect. Oxford: Pergamon Press. Dollard, J., Doob, L. Miller, N. Mowrer, O., \& Sears, R. (1939). Frustration and agression. New Haven: Yale University Press. 
Freyre, G. (1933/n.d.). Casa-Grande \& Senzala. Formação da Família Brasileira sob o Regime de Economia Patriarcal. Lisboa: Livros do Brasil.

Habermas, J. (1984). The theory of communicative action, Vol 1 (T. McCarthy, TransI.). Beacon Press: Boston. (Original work published 1981)

Judt, T. (2010). Um tratado sobre os nossos descontentamentos (M. Felix, Port. transl., III fares the Land]. Lisboa: Edições 70.

Lewin, K. (1948). Resolving social conflicts. New York: Harper \& Row.

Monteiro, M. B. (2002). Conflito e negociação entre grupos. In J. Vala \& M. B. Monteiro (Eds.), Psicologia Social (5 ${ }^{\text {th }}$ ed., pp. 411-456). Lisboa: Fundação Calouste Gulbenkian.

Mugny, G. (1982). The power of minorities. London: Academic Press.

Mugny, G. (Ed.) (1985). Psychologie sociale du développement cognitif. Berne: Peter Lang.

Rabbie, J. M., \& Horwitz, M. (1969). Arousal of ingroup-outgroup bias by a chance win or loss. Journal of Personality and Social Psychology, 13, 269-277.

Rabbie, J. M., Schot, J. C., \& Visser, L. (1989). Social identity theory: a conceptual and empirical critique from the perspective of a behavioural interaction model. European Journal of Social Psychology, 19, 171-202.

Sanchez-Mazas, M., \& Licata, L. (Eds.). (2005). L'Autre: regards psychosociaux. Grenoble: Presses Universitaires de Grenoble.

Sherif, M. (1958/2001). Superordinate goals in the reduction of intergroup conflict. In M. A. Hogg \& D. Abrams (Eds.), Intergroup relations: Essential readings (pp. 64-70). Philadelphia: Psychology Press.

Sherif, M. (Ed.) (1962). Intergroup relations and leadership. New York: Wiley

Sherif, M. (1966). Group conflict and co-operation: Their social psychology. London: Routledge \& Kegan Paul.

Sherif, M., Harvey, O. J., White, B. J., Hood. W. R., \& Sherif, C. W. (1961). Intergroup conflict and cooperation: The Robber's Cave experiment. Norman: University of Oklahoma Institute of Intergroup Relations.

Tajfel, H. (1972a). Experiments in a vacuum. In J. Israel \& H. Tajfel (Eds.). The context of social psychology: A critical assessment (pp. 69-119). London: Academic Press.

Tajfel, H. (1972b). La catégorisation sociale. In S. Moscovici (Ed.), Introduction à la psychologie sociale, Vol. 1 (pp. 272-302). Paris: Larousse.

Tajfel, H. (1978/1983). Grupos Humanos e Categorias Sociais. Vol. 2 (L. Amâncio, Port. transl.). Lisboa: Livros Horizonte. [Original ed.: H. Tajfel (1978). The psychological structure of intergroup behaviour. In H. Tajfel (Ed.) Differentiation between social groups: Studies in the social psychology of intergroup relations. London: Academic Press.]

Tajfel, H. (1984). Intergroup relations, social myths and social justice in social psychology. In H. Tajfel (Ed.), The social dimension. European developments in social psychology: Vol. 2 (pp. 695-715). Cambridge. Cambridge University Press.

Tajfel, H., Flament, C., Billig, M., \& Bundy, R. (1971). Social categorization and intergroup behaviour. European Journal of Social Psychology, 1, 149-177.

Tajfel, H., \& Turner, J. (1979/2001) An integrative theory of intergroup conflict. In M. A. Hogg \& D. Abrams (Eds.), Intergroup relations: Essential readings (pp. 94-109). Philadelphia: Psychology Press.

Taylor, D., \& Moghaddam, F. (1994). Theories of intergroup relations: International social psychological perspectives. London: Praeger. 
Triandis, H. C. (1979). Commentary. In W. G. Austin \& S. Worchel (Eds.), The social psychology of intergroup relations (pp. 321-334). Monterey: Brooks/Cole.

Turner, J. C., Hogg, M. A., Oakes, P. J., Reicher, S. D., \& Wetherell, M. S. (1987). Rediscovering the social group: A self-categorization theory. Oxford: Blackwell.

Turner, J. C., \& Oakes, P. J. (1986). The significance of the social identity concept for social psychology with reference to individualism, interactionism and social influence. British Journal of Social Psychology, 25, 237-252.

Valentim, J. P. (2003). Identidade e Lusofonia nas Representações Sociais de Portugueses e de Africanos. Tese de doutoramento. Coimbra: Universidade de Coimbra.

Valentim, J. P. (2005a). Luso-tropicalismo e lusofonia: perspectivas psicossociais. Via Latina, $6(2), 67-73$

Valentim, J. P. (2005b). Sobre Gilberto Freyre e a "adversidade ao mestiçamento". IberPsicologia. Anales de la Revista de Psicologia General y Aplicada, 10.5.7. [available on http://fs-morente.filos.ucm.es/Publicaciones/lberpsicologia/lisboa/pires2/pires2.htm]

Valentim, J. P. (2008). Identidade pessoal e social: entre a semelhança e a diferença. Psychologica, 47, 109-123.

\section{Conceitos teóricos de Sherif e estudos sobre relações entre grupos: notas para uma interdependência positiva}

Os conceitos teóricos de Sherif no domínio das relações entre grupos não são um mero marco histórico no superar das perspectivas individualistas neste domínio. Podem ser também, actualmente, instrumentos teóricos úteis para quem se interessa pelo estudo do funcionamento da sociedade. Neste artigo defende-se que a psicologia social pode beneficiar com a discussão e uso dos conceitos de Sherif para produzir uma análise mais compreensiva e integrada no estudo das relações entre grupos que aquela que por vezes decorre de uma estrita utilização do modelo da categorização. Isso é aqui ilustrado com dois exemplos de identidades supranacionais (a identidade europeia e a comunidade lusófona) cujo estudo pode ganhar com a utilização das ideias de Sherif, em especial, a noção de objectivos supra-ordenados. Contudo, apesar da pertinência e utilidade dos conceitos de Sherif, também devem ser assinaladas algumas fraquezas da teoria dos conflitos reais, designadamente, 0 pressuposto de que o conflito é sempre e inevitavelmente negativo. Questiona-se esta ideia tendo em conta o caso de grupos desfavorecidos que se encontram em situações de injustiça e também com base nos dados que põem em evidência os benefícios do conflito socio-cognitivo, provenientes de dois campos de pesquisa nos estudos europeus de psicologia social: a psicologia social do desenvolvimento e o estudo da influência minoritária.

PALAVRAS-CHAVE: teoria dos conflitos reais, relações entre grupos, identidade social, identidade nacional 


\section{Concepts théoriques de Sherif et études sur les relations entre groupes: notes pour une interdépendance positive}

Les concepts théoriques de Sherif dans le domaine des relations entre groupes ne sont pas tout simplement une importante référence historique pour surpasser les perspectives individualistes dans ce champ. Ils peuvent être aussi, actuellement, des instruments théoriques utiles pour les recherches qui s'intéréssent à l'étude du fonctionnement de la société. Dans cet article on soutient l'idée selon laquelle la psychologie sociale peut profiter de la discussion et de l'usage des concepts de Sherif pour produire une analyse plus compréhensive et intégrée dans l'étude des relations entre groupes que celle qui découle, parfois, d'une utilisation stricte du modèle de la catégorisation. Ce point de vue est ici illustré aves deux exemples d'identités supranationales (l'identité européenne et la communauté lusophone) dont l'étude peut gagner avec l'utilisation des idées de Sherif, en spécial la notion d'objectifs supra-ordonnés. Toutefois, malgré la pertinence et l'utilité des concepts de Sherif, certaines faiblesses de la théorie des conflits réels doivent aussi être signalées, notamment la préssuposition que le conflit est toujours et inévitablement négatif. On questionne ici cette idée prenant en compte le cas des groupes défavorisés qui se trouvent dans des situations d'injustice et aussi se fondant dans les données qui mettent en évidence les effets bénéfiques du conflit socio-cognitif et qui proviennent de deux champs de recherche dans les études européennes en psychologie sociale: la psychologie sociale du développement et l'étude de l'influence minoritaire.

MOTS-CLÉS: théorie des conflits réels, relations entre groupes, identité sociale, identité nationale 